\section{Discoveries at Velikie Bolgary}

THE site of Bolgary on the Volga just below the confluence with the Kama has been known since the eighteenth century. It is interesting as the most northerly outpost of Islam. . It is marked by ruins of mosques, baths and other public buildings characteristic of a Moslem town, and on its site have been found tiles, fragments of fresco, mirrors and coins. The inhabitants were Turks of a sort; another branch of them settled in the Balkans and founded the Bulgar State., On the Volga the Chuvash are their descendants. Their State is mentioned by all the Musulman geographers. After some prosperity lasting from the tenth to the thirteenth century, it was destroyed by the Mongols, but the city lingered on for another century. Its place has been taken by Kazan. Prof. Alexey Smirnov reports that from 1938 until the outbreak of the war with Germany he'has been excavating the site, the White and Black Halls (baths), a minaret, mausolea, a large paved square and remains of wooden houses and grain pits. The baths show the traditional perfection of the eastern bath. The finds are being carefully preserved for the Autonomous Tartar Republic.

\section{Portuguese Anthropological Studies}

Prof. A. A. Mendes Corrêa has published, from the Institute of Anthropology of the Faculty of Sciences of the University of Oporto, under the title "Da Raça el do Esperito", a volume of essays on various anthropological subjects ranging from crime from an anthropological point of view to the Japanese in Brazil ; from a study of the Portuguese people to race and moral values. Prof. Mendes Corrêa is well known as an anthropologist and many of his ideas will be found interesting. It is perhaps a pity that he has chosen to write in a language which cannot be said to be universally known. The same author recently read a paper before the sixteenth congress of the Spanish Association for the Advancement of Science, which was held at Zaragoza in 1940 . His subject was "Perspectivas duma anthropologia citológica". Once again, however, the language difficulty supervenes. This could perhaps have been overcome by the addition of short summaries in French or English.

\section{Coloured Arc in the Sky}

Miss F. E. Penrose states that on February 8, between 4 and 4.15 p.m. B.S.T., she saw from the East Cliff, Bournemouth, "a portion of a 'bow' resembling a rainbow almost overhead. About a fifth of the arc-the southern portion only-could be seen against a blue sky mottled with white cloud. Had the are been complete, it would have formed a ring very slightly south of the zenith. It was not raining at the time",

There can be little doubt that this was the rather rare 'are of contact' to the halo of $46^{\circ}$, described by Dr. F. J. W. Whipple in the "Dictionary of Applied Physics", vol. 3, p. 532, for although no such halo is mentioned, the halo, if visible at all, is apt to be faint, and the coloured arc at its best is a magnificent display of the colours of the spectrum. The Bournemouth description is in general agreement with a similar appearance seen near Stroud (Glos.) in the early afternoon of January 26, except that near Stroud both the $22^{\circ}$ and $46^{\circ}$ haloes were present, together with part of the mock sun ring and two mock suns, while the arc seemed to the present writer to be centred on the zenith. A similar coloured arc was seen in Wiltshire on January 21. This are is apt to be too high in the sky to attract notice in normal times, and may seem to be getting more common merely because so many people now system. atically examine all parts of the sky that an appearance of this kind can scarcely be overlooked.

\section{Eradication of Wild Orion}

WILD onion is a troublesome weed on heavy land in many English counties as well as in vast areas of the United States and Central Europe. It poses a serious problem to the farmer as it has the property of tainting milk and wheat, and once established is extremely difficult to eradicate from either pasture or arable land. Hitherto only partial success has attended measures for its control, but Mr. J. R. Tinney of Saffron Walden has worked out a specific scheme of crop rotation by means of which he has successfully rid his own land of the pest. Details of the method are given in Agriculture, 49, 155 (1943). The essential features of the scheme are: (1) a succession of spring-sown crops for six years, the first of which should be potatoes or roots, there being two cleaning crops during the first three years, and (2) the omission of autumn sown crops or bare fallow. The time of ploughing is specifically stated, and this must be rigidly adhered to in order to give the plants a check when most vulnerable. Drainage is also important. Seven rules of procedure are given with the reasons why they should be followed, and provided the farmer has sufficient perseverance to carry out the instructions, there seems every hope that his efforts will be attended with permanent success.

\section{History of the Tomato}

A SHORT paper on "The Evolution of the Cultivated Tomato" by Dr. L. C. Luckwill (J. Roy. Hort. Soc., 68, Pt. 1 ; January 1943) shows that only one of the six species of the genus Lycopersicum is cultivated, though several wild kinds have supplied parentage for improvement by hybridization. Most primitive forms belong to the sub-species Galeni of Lycopersicum esculentum, and a good deal of improvement by selection was probably done, by the natives of South America. The plant was first cultivated in Europe on the coastal plains of Spain and Portugal about 1535 A.D., spreading via Italy and Holland to Great Britain. This early cultivation yielded irregular, fasciated fruits, which were the typical produce until more than three centuries later. The change to a regular fruit is thought to have arisen as the result of a reverse mutation from the recessive to the dominant condition. Suggested lines for future improvement are the attainment of hybrid vigour (heterosis) by the crossing of well-chosen parents.

\section{Co-operation in Research}

RESEARCH workers will be interested in the way in which the method of co-operation in scientifie investigation has been developed at the Franklin Institute (Reports of the Biochemical Research Foundation of the Franklin Institute, 6, 1940-41). The department has heretofore been the unit for achieving co-opera. tion, and in an endeavour to attain closer correlation, the rigid division into departments has been elimin. ated. Under the new scheme, a round-table conference takes the place in part of the former 